Compendium de terminologie chimique.

Recommandations IUPAC et Lexique anglais/

français, $2^{e}$ édition. Préparé par Jean-Claude

Richer. Editions Tec \& Doc, Paris (1999), pp. viii +

1-646. ISBN 2-7430-0356-1. [French translation of

IUPAC “Gold Book", Compendium of Chemical

Terminology, $2^{\text {nd }}$ edition. Compiled by Alan D.

McNaught and Andrew Wilkinson. Blackwell

Science (1997), pp. vii + 1-450]

This French translation of the $2^{\text {nd }}$ edition of the IUPAC "Gold Book" was prepared by Prof. Jean-Claude Richer, Department of Chemistry, University of Montreal, Quebec, Canada. It is available from Editions Tec \& Doc, 11 rue Lavoisier, F-75384 Paris Cedex 08, France.

The $2^{\text {nd }}$ edition of the IUPAC "Gold Book" represents a very substantial enhancement of the $1^{\text {st }}$ edition. In the twelve years since publication of the $1^{\text {st }}$ edition, IUPAC has revised and updated most of the original definitions, and has produced new glossaries of terms in many areas of chemistry not previously covered. Around 7000 entries cover all the traditional areas of chemistry and also growing fields such as stereochemistry, photochemistry, organic class names, atmospheric chemistry, catalysis, biotechnology, chromatography, toxicology, and bioanalytical chemistry. The resulting compendium, like the $1^{\text {st }}$ edition, contains only definitions approved by international consensus, and thus can be regarded as truly authoritative. It is an essential reference resource for chemists everywhere.

\section{New Publication from the Pan American Health Organization}

\section{Biodiversity, Biotechnology, and Sustainable Development in Health and Agriculture: Emerging Connections}

1998, 248 pages (English; also available in Spanish), ISBN 92-75-11560-5, USD 32.00 (Special offer: USD 22.00); In developing countries: USD 24.00 (Special offer: USD 17.00), Order Code SP 560. PAHO Sales and Distribution Center, P.O. Box 27, Annapolis Junction, MD 20701-0027, USA; E-mail: paho@pmds.com; Tel.: +1 301617 7806; Fax: +1 301206 9789; Web site: http://publications.paho.org/.

This publication is a compendium of articles prepared by economists, sociologists, lawyers, biological sciences researchers, and other health professionals that explores the connections among biodiversity, biotechnology, and sustainable development in developing countries from the points of view of their different professions. The book focuses on two aspects of special interest to human health: drug discovery and improved nutrition through advances in agriculture.
The first section discusses different bioprospecting ventures-including the now famous agreement between Merck \& Co. and Costa Rica's National Institute for Biodiversity (INBio) — and suggests policy options for potential host countries. Subsequent sections explore such issues as costs, scientific and resource requirements, and economic prospects of different drug development models; how biodiversity and biotechnology can team up to establish a high-yield, sustainable agriculture; the legal ramifications of intellectual property rights, fair compensation for indigenous knowledge, and different contractual arrangements; how to assess biodiversity's economic value; and domestic and international policy implications of the use and conservation of biodiversity. A final section discusses whether biodiversity - " green gold" — will, in fact, become Latin America's and the Caribbean's new competitive advantage.

Emerging Connections is a must-read for those setting national biodiversity policies; teams working on the national strategies and action plans needed to implement the Biodiversity Conference; environmentalists; scientists and business people entertaining bioprospecting ventures; lawyers; and nongovernmental organization (NGOs) working on health, sustainable development, or environmental issues.

\section{New Publications from the World Health Organization}

\section{Copper, Environmental Health Criteria No. 200}

1998, xxii +360 pages (English with summaries in French and Spanish), ISBN 92-4-157200-0, CHF 72.-/ USD 64.80; In developing countries: CHF 50.40, Order No. 1160200 . WHO Distribution and Sales, CH1211 Geneva 27, Switzerland; E-mail: Publications@ who.ch; Tel.: +41 2279124 76; Fax: +41 2279148 57.

This book evaluates the risks to human health and the environment posed by exposure to copper, a malleable metal found naturally in a wide variety of mineral salts and organic compounds, and in the metallic form. Copper is an essential element for all biota. It is widely used in cooking utensils and water distribution systems, in fertilizers, bactericides, fungicides, algicides, and antifouling paints, and in animal feed additives and growth promoters. Industrial applications include use as an activator in froth flotation and sulfide ores, in the production of wood preservatives, in electroplating, and in the manufacturing of azo-dyes.

The report opens with a description of the array of sampling techniques, preparation, and analytical methods available for quantifying copper in environmental and biological samples. Section 2 covers sources of 